\title{
The Portrait of Provision of Indonesian Elementary School Teachers in Malaysia
}

\author{
Rambat Nur Sasongko $^{1 *}$, Abang Ismail bin Abang Haji Julhi², and Bambang Sahono ${ }^{3}$ \\ ${ }^{1}$ Professor, Faculty of Education, Bengkulu University, Indonesia \\ ${ }^{2}$ Associate Professor, Institut of Teacher Education, Kuching Sarawak, Malaysia \\ ${ }^{3}$ Professor, Faculty of Education, Bengkulu University, Indonesia
}

\author{
DOI: $10.36348 /$ JAEP.2019.v03i10.003 \\ | Received: 03.10.2019 | Accepted: 11.10.2019 | Published: 21.10.2019
}

*Corresponding author: Rambat Nur Sasongko

\section{Abstract}

The existence of Indonesian Elementary Schools in Malaysia is difficult to detect. That is because there are many variations in the types of basic education, the status of parents in Malaysia as illegal workers, and the location of the organization in accordance with their workplace. All of the basic education units must all be prepared by the Indonesian government. This study aims to portray the provision of teachers who will be assigned to teach Indonesian primary schools in Malaysia. The research uses a case study method with a qualitative approach. The research subjects were the Indonesian teacher provider authority, consulate general, and the principal of the Indonesian primary school/ CLC in Malaysia. Data collection techniques with interviews, observation and focus group discussions. Data is processed inductively with flow analysis. The results showed that the provision of Indonesian primary school teachers in Malaysia had not met the needs in the field. Many problems in the field, among others: the provision of teachers has not been able to meet the number and quality of competencies, variations in basic education patterns, lack of guidance, limited learning space, and future unclear teacher career development. Suggestions to the authority of the teacher supply provider in order to be able to meet the teaching staff in accordance with the needs of the field and be able to overcome the shortage of teacher staff.

Keywords: teacher provision, Indonesian primary school, Malaysia.

Copyright @ 2019: This is an open-access article distributed under the terms of the Creative Commons Attribution license which permits unrestricted use, distribution, and reproduction in any medium for non-commercial use (NonCommercial, or CC-BY-NC) provided the original author and sources are credited.

\section{INTRODUCTION}

The discussion about the world of work is never finished. Provision of employment opportunities is always out of balance with the needs of the workforce [1]. One of the impacts is migration to other places [2]. Classic problems in Indonesia until now, one of which is the exodus of job seekers to the kingdom of Malaysia. That is because the world of work in Indonesia has not been able to accommodate all job seekers. Malaysia as a neighboring country is the main destination for job seekers. This condition is based on the location closer to Indonesia and also more flexible in accepting prospective workers. The Kingdom of Malaysia is the country that holds the most Indonesian workers. In 2018 the number of Indonesian workers working in Malaysia was 2.7 million [3]. This condition is a dilemma for the nation.

One problem that arises with Indonesian workers in Malaysia is that one of the problems is the children of Indonesian workers who need basic education. The number of children of Indonesian workers in Malaysia is large. The number of children in 2018 is 28,000 children [3, 4]. Of those, 18,200 children $(65 \%)$ are elementary school students. They all need education in elementary school. Indonesian primary schools in Malaysia are 155 schools, and / or community learning centers (CLC) [3]. This amount has not yet been fully detected, due to the illegal status of workers and distribution to various hard-to-reach plantations.

Indonesian elementary schools and CLC need teachers. There are a number of problems regarding teacher needs. These problems include a shortage of teachers, teachers in schools that are less professional, and have a problem of cultural adaptation. Based on sources from Pikiran Rakyat [3] and the Ministry of Education and Culture [4] the problem of teacher shortages includes not every class having a permanent teacher, the teacher functioning as a class teacher, the teacher being a multi-grade teacher, a place of learning in the form of CLC, elementary school teachers are 
unable to serve all class, there are teacher assistants who do not qualify as teachers (not graduates of elementary teacher education). The problems of elementary school teachers are less professional, among others elementary school teachers are less able to master all subject matter in elementary schools, lack mastery of multigrade learning methods, lack of mastery of national culture (Indonesia and Malaysia), and lack of sophisticated information technology. In addition to this, teachers experience cultural problems including being less adaptive to Malaysian culture, lacking the value of Pancasila and the love of the motherland (Indonesia), lack of planting religious material correctly, parents less intending to help children's learning at home related to Pancasila, love of land water, and religious material that is adopted. Other problems, such as immigration, housing, salaries, etc. also contribute to the dynamics of teachers in other countries.

Problems related to the needs of elementary school teachers are very important and urgent to be solved. That is because it can cause negative impacts, such as: low quality of education services, chain duping, structural poverty that follows their parents, low learning achievements of children, children do not love the culture of the Indonesian nation, children are less familiar with the philosophy of the nation's Pancasila, children lack understanding of religion / beliefs it follows, the quality of teachers is low and less professional, the quality of Indonesian children's education in Malaysia is less able to compete, teachers are less adaptive to Malaysian culture, and teachers are less adaptive to information technology in the industrial revolution era 4.0 .

The above problems are related to teacher management problems [5]. The management of Indonesian primary school teachers in Malaysia is less effectively managed. According Sasongko that teacher management that is less effective can lead to a risk of "dominoes" to the low quality of the teacher itself, the quality of students, the quality of education, and the quality of the nation [6]. This may not be in accordance with national education standards, especially not in accordance with the standards of educators set by the government [7]. This condition is very dangerous if it cannot be completely resolved [8, 9].

This study seeks to photograph how the provision of Indonesian elementary school teachers in Malaysia. The formulation of the problem of this research are: "What is the portrait of the provision of Indonesian elementary school teachers in Malaysia?" This problem consists of how to plan the provision of teachers, how is the teacher recruitment system, how is the placement of teachers, and how are the problems faced by the provision of teachers?
This study aims to photograph in detail about the provision of Indonesian elementary school teachers in Malaysia. This objective will describe in detail the planning of teacher provision, the teacher recruitment system, placement of teachers, and the problems faced with the provision of teachers

The benefits of this research can be described among others about the portrait of the provision of Indonesian elementary school teachers in Malaysia as a basis for the development of teacher management science. In addition to this, this research is a database that can be used to improve and / or improve the performance of Indonesian elementary school managers in Malaysia, the government in improving the performance of elementary school teachers, and the government in educating the life of the nation in various parts of the world.

\section{METHODOLOGY}

This research uses a case study method with a qualitative approach $[10,11]$. The case study seeks to describe in detail the portrait of the provision of Indonesian primary school teachers in Malaysia. The results of the study are explained descriptively and in depth.

Case study subjects include the authorization provider of Indonesian primary school teachers in Malaysia, the Directorate General of Teachers and Education Personnel, the Ministry of Education and Culture in Jakarta, the Consul General of the Republic of Indonesia in Malaysia, and the principal of Indonesian primary schools in Malaysia. The subjects and respondents of the study were chosen in a purposive manner (purposive and snow ball sampling) [10]. In addition to this, various writings on the website about the recruitment of Indonesian teachers in Malaysia are also used as a source of data for comparison and deepening.

Data collection techniques were carried out by in-depth interviews (by phone and WhataApp), observation, documentation study (analysis of media coverage), and focus group discussions with research subjects $[10,11]$. Interview techniques are used to explore information about providing primary school teachers. Observation and documentation studies are used to support by looking at evidence from available documents. Focus group discussions are used to obtain the principal's views on the provision of teachers.

Data analysis techniques are used with a qualitative approach "flow analysis" [10, 11]. The steps of data analysis are by gathering data and information, reducing data, data exposure, data verification, and conclusions. This step is done repeatedly, until obtaining and answering problems into a meaningful whole pattern. The formulation of the pattern may be a 
new phenomenon, a new field theory (grounded theory), or a thesis that is truly original $[10,11]$.

\section{RESULTS AND DISCUSSION Results}

The provision of Indonesian primary school teachers in Malaysia is organized by the Directorate General of Teachers and Education Personnel, the Ministry of Education and Culture of the Republic of Indonesia. In terms of organization related to teacher recruitment under the responsibility of this directorate. Indeed impressed centralistic. This is because the authority to supply teachers abroad is carried out with a one-stop control system. The needs of Indonesian teachers abroad are coordinated between the Ministry of Foreign Affairs and the Ministry of Education and Culture.

Technically the provision of Indonesian primary school teachers in Malaysia is controlled by two ministries. The Consulate General under the Indonesian Embassy in various cities in Malaysia has the authority to oversee the existence of the Indonesian people in its territory. For example the Indonesian Consulate General in Johor Bahru, Penang, Kota Kinibalu, Kuching, or Tawau identified the needs of Indonesian schools in Malaysia. School needs include various things, such as identification of school children, provision of teachers, provision of learning places, school facilities and infrastructure, finance, community relations, and other needs. The need for teachers was also coordinated by the Indonesian Consulate General. After all the needs relating to the needs of teachers are prepared, the Indonesian Consulate General reports to his supervisor, the Indonesian Embassy in Kuala Lumpur, Malaysia. The embassy reports to the Indonesian Ministry of Foreign Affairs. The Indonesian Ministry of Foreign Affairs coordinates with the Indonesian Ministry of Education and Culture. The Ministry of Education and Culture instructs the Directorate of Teachers and Education Personnel to recruit and supply teachers. Thus the bureaucratic system that is carried out in the supply of elementary school teachers.

The bureaucracy coordinating the supply of Indonesian primary school teachers in Malaysia is indeed complicated. That is because the Consulate General does not have the authority to recruit teachers directly. Other problems also arise, such as the form of a place of learning in the form of a community learning center (CLC). This form of learning has a variety of age children, so it does not require teachers of different classes. This form does not resemble elementary schools, but is more like CLC, so that patterns and learning systems are different from regular primary schools. This condition also requires teachers who are all competent, such as being able to teach dual classes, able to teach small classes, able to teach in open spaces, able to teach with simple facilities, and so on.
There are two patterns in the management of teacher provision according to the type of educational institution that is held. The first type is elementary school. Indonesian public elementary schools are located in Kuala Lumpur. The provision of teachers does not have significant problems, because teacher management is the same as that in Indonesia in general. The second type is the school in the form of CLC. These CLCs are widely distributed across the tip of the peninsula of North Malaysia to Tawau Sarawak. They are difficult to detect because they follow the pattern of labor migration. The management of teacher provision in CLC is very complicated. Formally the recruitment is carried out by the Indonesian Ministry of Education and Culture. But they also do their own recruitment which tends to pay less attention to the quality of teachers, teacher competencies, and teacher authority.

Historically the provision of Indonesian primary school teachers in Malaysia emerged from a very long history of migration culture. Provision of teachers begins with sending teachers to Malaysia. The purpose of sending teachers is to address the education of Indonesian migrant workers' children who cannot go to school in Malaysia. The reality on the ground that occurs in Indonesian workers who work in Malaysia has difficulty in obtaining education for their children, due to the status of their children from parents as illegal workers. Illegal workers generally work in the plantation and livestock sectors. The Malaysian government does not recognize illegal migrant workers. Likewise with their children. The impact is the children of Indonesian workers cannot attend school in educational institutions owned by the Kingdom of Malaysia.

Seeing the condition of this problem, the Ministry of Education and Culture (Kemendikbud) of the Republic of Indonesia, in this case the Directorate General of Teachers and Education Personnel and the Directorate of Basic Education Teacher Development, in 2006, held a Joint Working Group (JWG) Meeting 4th in Langkawi-Malaysia. Since 2006 finally the Government has assigned 109 non-civil servant teachers, with a two-year contract status to become Indonesian children's teachers in Malaysia, to teach at Sabah Malaysia CLC. This CLC is an educational institution formed by the community of migrant workers as a vehicle to meet the educational needs of their children. The main task of the teacher is to teach, ie to teach reading, writing and arithmetic (3r).

In 2008 Kota Kinabalu Indonesia School (KKIS) was established with the status of the Indonesian government owned land, buildings and equipment. KKIS has 384 elementary school students. In Sabah there are 263 CLC units. The type of education at the community learning center is nonformal, the ownership status of facilities belonging to 
the management of the Sabah plantation. That year teachers were sent to teach at the Indonesian CLC in Malaysia with the aim of: (1) providing educational services for migrant workers' children who did not have access to education at the place where their parents worked in Malaysia, (2) achieving national education goals, (3) growing the values of unity, building a sense of nationality, instilling personality, and the value of pride as an Indonesian citizen, and (4) increasing the 9year compulsory education program.

In 2017 the Ministry of Education and Culture of the Republic of Indonesia sent 83 teachers to the Indonesian Representative Head in Malaysia. The teacher was recruited according to procedures and provisions in Indonesia. Including elementary school teachers must meet $\mathrm{S} 1$ qualifications and pass the selection. Subsequently the teacher was placed in Sabah as many as 73 people, Sarawak as many as 9 people, and 1 teacher in Johor Baru. The teacher sending activities have been carried out in eight stages. In 2018 100 teachers were sent.

In 2018, the number of Indonesian CLCs in Malaysia was 294 units. The CLC is 155 units for elementary school and 139 units for junior high school. This year the teacher recruitment system for CLC has been running systematically and in an orderly manner. Organizers by the Directorate General of Teachers and Education Personnel, Ministry of Education and Culture. Prospective teachers recruited must fulfill bachelor's degrees, have educator certificates, and pass competencies.

In 2019 the Directorate of Teachers and Education Center, Ministry of Education and Culture, again recruited teacher candidates for CLC on a twoyear contract. They will be recruited by 100 teachers. They will be placed in the Kota Kinabalu, Kuching and Tawau areas. The objectives of this program are to: (1) meet the needs of teachers at CLC, provide educational services for the children of Indonesian migrant workers who do not yet have access to education at the place where their parents work in Malaysia; (2) developing the potential of students to become human beings who have faith and are devoted to God Almighty, have good character, are healthy physically and spiritually, are knowledgeable, capable, creative, independent, and become democratic and responsible citizens; and (3) building a sense of nationality, fostering the values of unity, preserving culture and instilling personality and pride as Indonesian citizens.

Prospective teachers recruited are not civil servants. The requirements include: Bachelor (S1) minimum cumulative achievement index of 2.75 , has an educator certificate, has two years of teaching experience, has computer skills, has life skills, is free of narcotics, is healthy, has a permit from parent / guardian / husband / wife, and register online. Then the candidates are ready to take part in the interview and performance selection by bringing the original file and the learning implementation plan of two themes for peer teaching. Acceptance selection is carried out in two stages, administrative selection and central level selection in the form of a series of tests. The tests are in the form of academic potential tests, interviews, and micro teaching. Recruitment was carried out at the Educational Personnel Education Institution, Indonesian Education University in Bandung, Semarang State University, Surabaya State University, Makassar State University, and Medan State University.

There are a lot of registrants. After being selected, they are gathered to be given the orientation of the assignment to become Indonesian school teachers in Malaysia. The orientation material includes his professional assignments to help Indonesian children in Malaysia, make children and parents aware of higher education, so they do not become workers with low education, teach with various problems and conditions in the field, and instill a love of the motherland. After being given an orientation they are sent to the Consulate General in Malaysia, to be placed in the destination CLC. They generally become contract teachers for two years and can extend the contract. They each month get a salary of Rp. 15,000,000 per month.

Teachers who teach at CLC encounter problems such as: the number of teachers who have not been able to meet the needs in the field, locations and places of learning that are not standardized by schools, must master various teaching materials for various ages, teaching is not focused on one field of study, classroom management is not good, limited learning facilities, poor CLC administration, poor teacher coaching, and rapid adaptation of life in the assignment.

According to several Indonesian workers in Malaysia, the CLC they established did not always obtain new teacher placements from the Indonesian government. They look for teachers themselves, recruit them, and provide orientation to hope that children become smart. They are voluntary teachers and do not have formal provisions as teachers who have educator certificates. They teach at CLC or home schooling around the workforce locations of Indonesian workers. The teachers generally work in accordance with the agreement with parents. They are paid not according to the standards set by the government. Problems found include: the number of teachers provided cannot meet the needs, teachers do not comply with learning standards, where learning facilities are incomplete, teachers teach various levels of age, teachers teach double classes, non-standard learning time, and evaluation systems are not not clear.

\section{DISCUSSION}

The provision of Indonesian primary school teachers in Malaysia, has three patterns. The three 
patterns are: (1) the pattern of teachers recruited as civil servants for primary schools in Kuala Lumpur, (2) the pattern of contract teachers for CLC in various workforce locations in Indonesia, and (3) the pattern of voluntary teachers for independent CLCs and home schooling.

The first pattern, teachers with state employees. They were recruited by the Ministry of Education and Culture. They were assigned to teach in Indonesian elementary schools in Kuala Lumpur. They are generally selected with a standard and good management system. They generally have good competence and have educator certificates. Academically and technically, they have a little problem with teaching. They received academic and career guidance from the school principal and officers who came from Jakarta. They are generally quite comfortable with assigned tasks, happy and prosperous.

The second pattern, teachers with contract status. These teachers were recruited by the Ministry of Education and Culture of the Republic of Indonesia with a standard selection system. They were placed in the CLC area of many Indonesian workers. The teachers were given the task with a two-year contract system. They can extend the contract after completion. They get a salary according to the work contract. They generally have serious problems such as teaching with limited facilities, dual classes, teaching for various ages of children, and so on.

The third pattern, teachers with voluntary status. They were recruited by the Indonesian migrant worker community. The recruitment system is not standard. The teacher teaches at CLC or home schooling near the worker's location. They do not have a structured contract. These teachers get voluntary salaries from parents. Problems found include nonstandard teaching patterns, teaching in accordance with limited facilities, teaching for various ages of children, giving modest salary, and unclear working period.

Three patterns of teacher provision have different systems and problems. According to Sasongko, Somantri, and Wachidi that different teacher management systems can cause different qualities [12]. This condition will bring a negative impact on learning outcomes [13]. Children will get poor service. They learn according to the conditions of the teacher in the field. Learning patterns are not standard. Although the learning objectives of children are able to read, write and count, they are of poor quality. Helens-Hard also said that poorly managed teachers can cause significant problems with learning services for children who are not good [8].

The teacher is a professional position $[6,7,9]$. They must qualify as undergraduate education, have educator certificates, pass competencies, and have a clear future career and salary system. Teachers who can meet these requirements are possible to become professional teachers. The Indonesian government has a teacher law and has set it in teacher standards. It is hoped that teachers can meet the national standards of teachers, and in turn can become professional teachers [14].

Provision of Indonesian primary school teachers in Malaysia, should duly meet national standards on teachers $[6,15,16]$. This standard regulates the quality of teachers, how to provide good services. This standard serves as a minimum limit for the eligibility of a teacher in order to guarantee the quality of teacher services in carrying out tasks. Teachers, who are recruited by the process of meeting the quality standards of teachers, can be guaranteed the implementation of their duties [15]. This condition can have a positive impact on teachers. The teacher supply system that occurs in the conditions of Indonesian elementary school teachers in Malaysia can be said to be lacking in standards and does not yet have a good process. That is because they are recruited through a different system of patterns, namely the pattern of recruiting teachers as civil servants, teachers as contract employees, and teachers as volunteers. This condition is not uniform and provides different services $[17,18]$.

The less uniform pattern of providing teachers can provide different professional services [17, 18]. Teachers who are recruited with the pattern of status as civil servants have a good fortune, because they are recruited by meeting standards. Besides this, career coaching is very clear. Teachers with contract employee status, have a good recruitment system, are placed in CLC, but do not have a clear career ahead. They are only limited to work contracts. But teachers with voluntary status, the recruitment process is almost nonexistent, working in CLC or home residents, there is no coaching, and neither has a career going forward. All three patterns are not standardized, and can have a negative effect on teacher services. Negative effects such as the implementation of teaching and learning processes that are not standard, the enthusiasm of different teachers, a different future [19].

Conditions as above need to be addressed immediately. Although the government already has a teacher law, national standards on teachers, and other regulations on teachers, in reality it must be implemented according to conditions on the ground. However, conditions on the ground need to be eliminated and dealt with properly. If this condition can be met, it can have a positive impact on teacher professionalism. Teachers can provide optimal educational services [20].

\section{CONCLUSION}

The portrait of providing Indonesian elementary school teachers in Malaysia has three 
patterns. The first pattern, teachers with the status of civil servants, is prepared with a management system that is in line with national standards. They are recruited with a selection system according to national standards, and they are placed in public elementary schools in Kuala Lumpur. The second pattern, teachers with contract employee status, is prepared with a recruitment system that is in line with national standards, but they are placed in CLC with a two-year work context. The third pattern, teachers with voluntary employee status, they are recruited voluntarily and do not comply with national standards, and they work in CLC or at home residents. Provision of teachers is done by selection, coaching, and different career development. They have a common vision, which is to provide access to education for children of migrant workers and children of Indonesian parents working in Malaysia. Serious problems that need to be addressed immediately include the provision of teachers not being able to meet the number or quality of competencies, variations in basic education patterns that keep busy, lack of guidance, limited learning space, and future unclear teacher career development.

Suggestions to the Ministry of Education and Culture, embassies and Indonesian people living in Malaysia, to synergistically assist the provision of teachers in accordance with national standards, the provision of appropriate learning facilities, and provide a good teacher career.

\section{ACKNOWLEDGMENTS}

This paper is an outcome of international collaborative research. To the University of Bengkulu Research Institute (Lembaga Penelitian dan Pengabdian kepada Masyarakat universitas Bengkulu), thank you for the facilities and financial support.

\section{REFERENCES}

1. Goldberg, J., \& Cole, B.R. (2018). Quality Management in Education: Building and Equity in Student Performance. Quality Management Journal, 9(4), 8-22, from https://www.tandfonline.com/doi/abs/10.1080/106 86967.2002.11919033

2. Septarina, L., \& Sasongko, R.N. (2019). Quality manajemen: Impact of leadership mobilization on institutional quality. International Journal of Research Science and Management, 6(5), 1-8, from

http://www.ijrsm.com/issues\%20pdf\%20file/Archi ve-2019/May-2019/1.pdf

3. Pikiran Rakyat: Mengajar Anak Para TKI, 100 Guru Dikirim ke Malaysia. (2018). from https://www.pikiran-

rakyat.com/pendidikan/2018/11/05/mengajaranak-para-tki-100-guru-dikirim-ke-malaysia432699

4. Kemendikbud: Cerdaskan Anak-anak Tenaga Kerja Indonesia di Malaysia, Pemerintah
Kirimkan 100 Guru. (2018). from https://www.kemdikbud.go.id/main/blog/2018/11

5. Bandur, A. (2009). The Implementation of School Based Management in Indonesia: Creating Conflict in Regional Level. Journal of NTT Studies, 1(1), 16-27

6. Sasongko, R.N. (2018). The implementation of national standards of education for school quality improvement facing the 21st century (Descriptive evaluative studies in various levels of schools in Bengkulu province of Indonesia). International Journal of Current Research in Life Sciences, 7(08), 2647-2651

7. Sasongko, R.N. (2018). The application of the national higher education standards (NHES) for quality improvement of world class graduates. EPH - International Journal of Educational Research, 2(12), 12-19

8. Helens-Hard, R. (2019). The employability selfassessment: identifying and appraising career identity, personal adaptability, and social and human capital. Management Teaching Review, 4(2), 6-13

9. Cassel, C. (2019). Challenges and conundrums: teaching and learning from a U.K. dean's perspective. Journal of Management Education, 43(3), 311-317

10. Burn, R.B. (2009). Introduction to Research Methods. Sidney: Longman

11. Miles, M.S. and Huberman, A.M. (2007). Qualitative Data Analysis: A Sourcebook of New Method, from http://www.ed.gov/databased/qualidata.Ed546735 34

12. Sasongko, R.N., Somantri, M., \& Wachidi. (2018). The new challenges of implementation of school principals standards in the era of Asean Economic Communities (AEC). International Journal of Recent Scientific Research, 9(9A), 28733-28736

13. Wener, B.S., \& Smith, A.B. (2019). Salary negotiation: a role-play exercise to prepare for salary negotiation. Management Teaching Review, 4(2), 14-26

14. Buil, I., Catalan, S., \& Martinez, E. (2019). Encouraging intrinsic motivation in management training: The use of business simulation games. The International Journal of Management Education, 17(2), 162-171

15. Esch, K.S.V. (2018). Teacher leaders as agents of change: creating contexts for instructional improvement for english learner students. The Elementary School Journal, 119(1), 211-224, from https://www.researchgate.net/publication/3265940 56

16. Barnes, N., Brighton, C.M., Fives, H., \& Moon, T.R. (2019). Literacy teachers' beliefs about data use at the bookends of elementary school. The Elementary School Journal, 199(3), 511-533, from 
https://www.researchgate.net/publication/3265930 14

17. Rehmani, A. (2006). Teacher education in Pakistan with particular reference to teachers' conceptions of teaching. Quality in education: Teaching and leadership in challenging times, 20(4), 495-524

18. Desai, S.V., Jabeen, S.S., Abdul, W.K., \& Rao, S.A. (2018). Teaching cross-cultural management: A flipped classroom approach using films. The
International Journal of Management Education, 16(3), 405-431

19. SASS (School and Staffing Survey). (2010). School Quality, School Management, and Teacher Quality, from http://nces.ed.gov/surveys/sass/issues2.asp

20. Bandur, A. (2009). The Implementation of School Based Management in Indonesia: Creating Conflict in Regional Level. Journal of NTT Studies, 1(1), $16-27$

\section{r.}

